\title{
ЗОВНІШНЬОЕКОНОМІЧНА ДІЯЛЬНІСТЬ
}

\author{
UDC 339.652-048.87(477)=111 DOI: https://doi.org/10.31617/zt.knute.2019(104)04 \\ KUDYRKO Liudmyla PhD (Economics), Professor, Professor at the \\ International Economic Relations Department \\ E-mail: I.kudirko@ukr.net \\ ORCID: 0000-0002-9089-7223 \\ SAMSONOVA Liliia \\ E-mail: samsonova.lilija.gov.ua@ukr.net \\ ORCID: 0000-0002-7285-9549 \\ of Kyiv National University of Trade and Economics \\ 19, Kyoto str., Kyiv, 02156, Ukraine \\ $\mathrm{PhD}$ (Economics), Assistant at the International \\ Economic Relations Department \\ of Kyiv National University of Trade and Economics \\ 19, Kyoto str., Kyiv, 02156, Ukraine
}

\section{COOPERATIVE COMPONENT OF THE IMPORT SUBSTITUTION STRATEGY OF UKRAINE*}

The thesis is based on the fact that in conditions of high level of the national economy dependence on imports of finished goods and intermediate goods, the mechanism, which is aimed to promote improvement of the structure and quality of international economic relations with participation of national business, is the activation of international cooperation ties. The characteristics of the import dependence level of some branches in Ukraine have been given and the prospects of solving the import dependence problem have been solved through the implementation of balanced import substitution strategy, part of which is the development of international inter- and intra-sectoral cooperation.

Keywords: import substitution strategy, import dependence, international cooperation, contract manufacturing, processing of tolling raw materials.

КудыркоЛ., Самсонова Л. Кооперационная составляющая стратегии импортозамещения Украины. Обосновано, что в условиях высокого уровня зависимости национальной экономики от импорта готовой продукции и товаров промежуточного потребления, механизмом, который будет способствовать совершенствованию структуры и качества международных экономических отношений с участием

* The preparation of the article to be possible by the support and funding of the Ukraine Ministry of Education and Science the research program №672 / 20 «The potential of import substitution in Ukraine in conditions of post-industrial economy emergence», which was implemented at the International Economic Relations Department of the KNUTE in 2019.

(C) Kudyrko L., Samsonova L.,2019 
национального бизнеса, необходима активизация международных кооперационных связей. Дана характеристика уровня импортозависимости отдельньх отраслей в Украине и раскрыты перспективы решения проблемы импортозависимости через реализацию сбалансированной стратегии импортозамещения, составной частью которой является развитие международной внутри- и межотраслевой кооперации.

Ключевые слова: стратегия импортозамещения, импортозависимость, международная кооперация, контрактное производство, переработка давальческого сырья.

Background. In condition of ultrahigh level of integration of modern Ukraine into the system of international economic relations it is quite logical to raise the question of overcoming or at least minimizing the risks of external dependence which are the result of this integration. Data on the structure of expenditures at both business level and households on imports are evidenced by this problem. Thus, the annual expenses of Ukrainians for imported goods are approaching 1 trillion UAH. According to the State Statistics Service the volume and proportion of imported consumer goods sold in the country over the past 14 years tend to increase: in 2005, imported products made $29,5 \%$ of all sold through the format of trade networks, in 2013 - already $42,8 \%$, and in $2018-64,7 \%$ of non-food products and $22,8 \%$ of food products. The problem is exacerbated by the growing alarming trend: the share of so-called «critical imports» (energy resources and raw materials) is decreasing each year, the costs of importing machinery and equipment needed to modernize the economy are also decreasing, while consumer goods manufactured abroad confidently strengthen the position on the domestic market [1].

Under such circumstances an effective implementation of the import substitution strategy with a wide range of instruments to restrict external procurement and support domestic production and exports could be a legitimate step towards counteracting this negative development. However, it is understandable that there is a complication for Ukraine to implement such a scenario. After all, there are a number of institutional, technological, economic, etc. barriers that make impossible «rigid» version of import substitution. It goes about Ukraine's commitments in the framework of agreements with international partners (WTO, EU), the technological insolvency of the national business to lock down all the links of the production or distribution chain on a range of commodity positions, lack of comparative advantages over a significant list of activities.

In our opinion, one of the balanced approaches to support and develop national business in the conditions of high level of import dependence of the national economy is an improvement of the structure and quality of this dependence by activating international cooperative ties with the participation of domestic enterprises.

Analysis of recent research and publications. The general theoretical and practical aspects of the application of the import substitution 
policy were reflected in the scientific works of representatives of the domestic and foreign economic schools, in particular in the studies of E. Rudnichenko [2], A. Mazaraki [3], T. Melnyk [4], I. Revak [5], S. Lupak [6], R. Britsky [7], A. Martins, J. Araujo [8], A. Adewale [9], S. Galiani, P. Somaini [10]. The issue of working-out import substitution strategy, taking into account the component of international co-operation as an instrument for overcoming high degree of import dependence of open-economy industries has not been yet adequately disclosed, and therefore requires more in-depth research.

Accordingly, the aim of the study is to reveal the potential of international industrial cooperation in order to reduce the critical level of import dependence of certain types of economic activity in Ukraine.

Materials and methods. The scientific basis of the research was revealed from the scientific publications of domestic scholars along with the data of the State Statistics Service of Ukraine and normative-legal acts of Ukraine. During the working over the article the following methods of scientific research were used: analysis and synthesis, statistical methods (comparison, collation, grouping, construction and analysis of series of dynamics, structural analysis), methods of economic-statistical analysis for determining the level of import dependence in some branches of the economy.

Results. The necessity to figure out and implement country's import substitution strategy is connected with the achievement of the parameters of hypertrophied import dependence of production and the demand to overcome the dependence of the domestic market upon imports of a wide range of consumer goods. International experience confirms that the majority of countries in the world import what they cannot manufacture or mine (critical imports), as well as what is more expensive to produce for them in comparison to traditional suppliers. Instead, in Ukraine a significant part of imported goods is made up of products that can be produced on their own with the quality and price comparable to foreign analogues, however which we still purchase in countries with significantly more expensive than domestic labor resources and lower level of employment. On the basis of the calculations, as it is shown in the table 1, there are those types of economic activity, according to which the indicators characterize the level of dependence on imports exceeding the acceptable limits.

As it can be seen from table 1, 12 of 42 (according to NACE) types of economic activity fall into the category of import-dependent, in particular: production of vehicles, trailers and semitrailers; computer manufacturing, electronic and optical products; manufacture of machinery and equipment not included in other groups; the production of chemicals and chemical substances in 2017 showed the import to output ratio is more than twice.

On the one hand, such results point onto negative trends in the national economy. At the same time, on the other hand, they reflect the profound transformations that our economy has been experiencing for some time in the direction of intensifying international cooperation ties. Most of the types of economic activity presented in the table 1 retained production potential, and in some cases increased due to orders from foreign counterparties. 


\section{Indicators of import dependence of certain types of economic activity of Ukraine, during 2015-2017}

\begin{tabular}{|c|c|c|c|c|c|c|c|c|c|}
\hline \multirow{2}{*}{$\begin{array}{c}\text { Name of the activity } \\
\text { by NACE }\end{array}$} & \multicolumn{3}{|c|}{$\begin{array}{l}\text { Import dependency } \\
\text { ratio, \% }\end{array}$} & \multicolumn{3}{|c|}{$\begin{array}{l}\text { Coefficient of own } \\
\text { production security }\end{array}$} & \multicolumn{3}{|c|}{$\begin{array}{l}\text { Coefficient of export } \\
\text { coverage of imports }\end{array}$} \\
\hline & 2015 & 2016 & 2017 & 2015 & 2016 & 2017 & 2015 & 2016 & 2017 \\
\hline $\begin{array}{l}\text { Production of motor vehicles } \\
\text { trailers and semitrailers }\end{array}$ & 94,49 & 134,00 & 155,27 & 0,57 & 0,46 & 0,42 & 0,20 & 0,13 & 0,10 \\
\hline $\begin{array}{l}\text { Production of ready to use } \\
\text { metal products except } \\
\text { machinery and equipment }\end{array}$ & 74,12 & 71,63 & 63,99 & 0,67 & 0,65 & 0,69 & 0,33 & 0,26 & 0,29 \\
\hline Rubber and plastic production & 1,69 & 62,92 & 61,82 & 0,68 &, 67 &, 68 & 0,23 & 0,21 & 0,23 \\
\hline $\begin{array}{l}\text { Production of } \\
\text { Equipment }\end{array}$ & 49,35 & 60,10 & 59,75 & 0,94 & 0,82 & 0,82 & 0,87 & 0,63 & 0,63 \\
\hline $\begin{array}{l}\text { of computers, } \\
\text { ind optical goods }\end{array}$ & 159,99 & 152,45 & 161,20 & 0,43 & 0,43 & 0,41 & 0,16 & 0,14 & 0,11 \\
\hline $\begin{array}{l}\text { Manufact } \\
\text { and appara } \\
\text { attributed }\end{array}$ & 125,29 & 159,67 & 159,01 & 0,65 & 0,49 & 0,48 & 0,57 & 0,34 & 0,31 \\
\hline $\begin{array}{l}\text { Production of basic } \\
\text { pharmaceutical products and } \\
\text { pharmaceuticals }\end{array}$ & 67,99 & 66,82 & 67,88 & 0,62 & 0,63 & 0,62 & 0,11 & 0,11 & 0,11 \\
\hline $\begin{array}{l}\text { Production of products oil } \\
\text { refining }\end{array}$ & 109,35 & 88,10 & 83,04 & 0,49 & 0,55 & 0,57 & 0,06 & 0,07 & 0,09 \\
\hline $\begin{array}{l}\text { Production of chemicals and } \\
\text { chemical substances }\end{array}$ & 7,47 & 116,84 & 121,66 & 0,61 & 0,53 & 0,51 & 0,35 & 0,23 & 0,22 \\
\hline Coal and brown coal mining & 92,92 & 70,45 & 88,74 & 0,53 & 0,59 &, 54 & 0,03 & 0,03 & 0,04 \\
\hline Raw oil and natural gas mining & 139,48 & 67,87 & 80,90 & 0,42 & 0,61 &, 56 & 0,02 & 0,04 & 0,04 \\
\hline $\begin{array}{l}\text { Textile production, } \\
\text { manufacture of clothes, } \\
\text { leather and other materials }\end{array}$ & 67,58 & 73,53 & 76,85 & 0,67 & 0,65 & 0,64 & 0,28 & 0,26 & 0,27 \\
\hline $\begin{array}{l}\text { Temporary placement and } \\
\text { catering organization }\end{array}$ & 57,16 & 60,17 & 72,40 & 0,70 & 0,68 & 0,63 & 0,25 & 0,22 & 0,20 \\
\hline
\end{tabular}

Source: calculated by authors on the basis of [11].

The bigger share in the structure of international co-operative ties of domestic enterprises is carried out in the form of operations on processing of tolling raw materials (table 2).

The calculated indicators of table 2 show that the key export positions on the basis of the tolling raw materials (tending to increase) are chemical products (product group VI) and light (commodity groups VIII, XI, XII, XX) industries, machine building (product group XVI), as well as goods of group $X$ which share made from the tolling raw materials is more than $26 \%$, and other types of manufacture (product group XX). Thus, in Ukraine the total export offer (in which the share of products made from tolling raw materials is more than $50 \%$ ) is the products of light industry only, that is the commodity groups VIII, XI and XII, which share in the commodity structure of export in 2017 amounted to $2,65 \%$. At the same time, the negative tendency to increase (up to 43,12\% in 2017 by almost 20 pp in three years) is deepening with the part of production from tolling raw materials in 
machine-building exports, the share of which in the commodity structure of Ukrainian exports during this period declined to $0,96 \%$ on the contrary.

Table 2

\section{Dynamics of indicators of using tolling raw materials in Ukraine for the period of 2014-2017}

\begin{tabular}{|c|c|c|c|c|c|c|c|c|c|}
\hline \multirow[t]{2}{*}{$\begin{array}{l}\text { The main } \\
\text { commodity groups }\end{array}$} & \multicolumn{3}{|c|}{$\begin{array}{c}\text { Share of finished goods } \\
\text { made from the tolling } \\
\text { raw materials } \\
\text { in commodity exports, } \\
\%\end{array}$} & \multicolumn{3}{|c|}{$\begin{array}{c}\text { Share of tolling } \\
\text { raw materials } \\
\text { in commodity imports, } \\
\%\end{array}$} & \multicolumn{3}{|c|}{$\begin{array}{l}\text { Coefficient of coverage } \\
\text { of import of tolling raw } \\
\text { materials by export } \\
\text { of finished products } \\
\text { made from it }\end{array}$} \\
\hline & 2015 & 2016 & 2017 & 2015 & 2016 & 2017 & 2015 & 2016 & 2017 \\
\hline Total & 7,87 & 8,90 & 9,51 & 5,56 & 6,31 & 6,35 & 1,40 & 1,43 & 1,39 \\
\hline $\begin{array}{l}\text { VI. Chemicals and } \\
\text { chemical substances } \\
\text { and related industries }\end{array}$ & 14,99 & 19,86 & 25,45 & 0,90 & 0,88 & 0,97 & 7,52 & 9,65 & 7,24 \\
\hline $\begin{array}{l}\text { VII. Polymer and } \\
\text { plastics materials, } \\
\text { goods made of them }\end{array}$ & 11,89 & 19,22 & 15,90 & 8,68 & 11,22 & 11,50 & 0,22 & 0,27 & 0,20 \\
\hline $\begin{array}{l}\text { VIII. Ra } \\
\text { and skin }\end{array}$ & 36,25 & 47,94 & 55,49 & 44,02 & 55,73 & 58,96 & 0,58 & 0,59 & 0,55 \\
\hline $\begin{array}{l}\mathrm{IX} . \mathrm{Wc} \\
\text { produc }\end{array}$ & 2,27 & 1,52 & 1,59 & 0,75 & 10,07 & 0,69 & 13,05 & 10,66 & 13,20 \\
\hline $\begin{array}{l}\text { X. Mass extracted from } \\
\text { wood or other fibrous } \\
\text { cellulose materials }\end{array}$ & 26,96 & 27,09 & 26,04 & 8,99 & 10,19 & 8,53 & 2,30 & 1,87 & 1,80 \\
\hline $\begin{array}{l}\text { XI. Textil } \\
\text { andtextile }\end{array}$ & 76,28 & 76,45 & 79,24 & 24,29 & 7,65 & 27,76 & 1,31 & 1,24 & 1,25 \\
\hline $\begin{array}{l}\text { XII. Shoes, } \\
\text { hats, umbrellas }\end{array}$ & 77,84 & 80,72 & 9,10 & 7,38 & 9,45 & 9,57 & 5,00 & 19 & 5,00 \\
\hline $\begin{array}{l}\text { XIII. Articles made of } \\
\text { stone, gypsum, cement }\end{array}$ & 1,40 & 2,00 & 3,39 & 1,24 & 1,41 & 1,36 & 0,68 & 0,92 & 1,23 \\
\hline \begin{tabular}{|l|} 
XIV. Natural or cultiva- \\
ted pearls, precious \\
orsemi-precious stones
\end{tabular} & 2,02 & 8,05 & 16,06 & 2,58 & 8,61 & 19,38 & 0,43 & 1,07 & 0,64 \\
\hline $\begin{array}{l}\mathrm{XV} \text {. Precious metals } \\
\text { andproducts from them }\end{array}$ & 1,85 & 3,22 & 2,88 & 3,43 & 5,27 & 4,97 & 2,47 & 2,89 & 2,10 \\
\hline $\begin{array}{l}\text { XVI. Machines, equip- } \\
\text { ment and mechanisms; } \\
\text { electrical engineering } \\
\text { equipment }\end{array}$ & 30,12 & 35,67 & 43,12 & 13,68 & 14,47 & 12,87 & 1,43 & 1,55 & 1,54 \\
\hline $\begin{array}{l}\text { XVII. Means of above- } \\
\text { ground transport, } \\
\text { aircraft, floating means }\end{array}$ & 14,79 & 4,45 & 3,23 & 0,40 & 1,02 & 0,24 & 20,48 & 1,71 & 2,48 \\
\hline $\begin{array}{l}\text { VIII. Devices and optical } \\
\text { apparatus, photography }\end{array}$ & 2,73 & 0,77 & 1,19 & 0,75 & 1,01 & 1,36 & 1,26 & 0,26 & 0,22 \\
\hline $\begin{array}{l}\text { XX Various industrial } \\
\text { goods }\end{array}$ & 31,65 & 33,17 & 40,44 & 4,40 & 5,42 & 4,99 & 5,87 & 6,28 & 6,95 \\
\hline
\end{tabular}

Source: calculated by authors on the basis of [12]. 
Thus, pointing out the dominant component in the sectoral structure of international co-operative ties, we would like to note that among inter media ryconsumption goods imported into Ukraine prevail (with at endency to in creaseover the analyzed period) tolling raw materials for light industry (commodity groups VIII and XI). In addition to the above-mentioned goods, a significant share in the structure of imports is (with adecline in 2017) the group of «various industrial goods» (product group XX), machinery, equipment and mechanisms (commodity group XVI) and polymer materials, plastics, and articles made of them (product group VII).

Quite logical is the question of national business share in the global value added chains due to location of operations on the processing of tolling raw materials in Ukraine? Which spheres and activities are distinguished by higher economic efficiency if mentioning the standpoint of comparative advantages? According to our assessment the greatest majority of added value is created when processing the tolling raw materials in wooden manufacture (commodity group IX), chemical (product group VI) and light industries (product group XII) as well as when producing various industrial goods (product group XX). At the same time, there are commodity groups, in which the import of tolling raw materials is not covered by the income from the export of finished products made from this raw material. This means that the imported tolling raw material is used for the production of goods from other commodity groups. In particular, this regards to polymeric materials, plastics and articles made of them (product group VII), unprocessed hides, peeled skin (product group VIII), precious or semi-precious stones (product group XIV) and optical and photographic apparatus (product group XVIII).

We admit the objectiveness of significant levels of import dependence for different types of activities in a situation, where industries and entire sectors of the national economy are embedded into international production networks and global added value chains. At the same time, one should not neglect the criteria of economic security, according to which the ratio of imports in total consumption under the stable state of the economy should notexceed $50 \%$. Instead, in Ukraine the level of import dependence is 80 $90 \%$ on some commodity positions [4].

The situation of strict dependence of certain sectors of the Ukrainian economy on imported finished goods and raw materials is of chronic nature and lasts almost from the time of Ukraine independence declaration. There is logical assumption that the country is not able to correct the situation solely during a long-term import dependence, which is a threat to economic security. Accordingly, it is proposed to consider the potential of international co-operation as one of the mechanisms for overcoming the import dependence of the Ukrainian economy. In this sense it is possible to shift the vector from the situation of «dependence» to the state of «cooperation».

The first precondition for the successful implementation of the import substitution strategy (macroeconomic level) should be its unconditional correlation with the national strategy for the development of the industrial 
complex, the state program of development of domestic industrial enterprises, the strategy for development of high-tech industries, etc. All these framework documents, in addition to their interconnectivity, should take into account specific features of some kinds of industries and types of economic activity, which are going to be the starting point for the choice of development instruments, in particular the cooperative ones.

For example, the experience has shown that the establishment of free economic zones or joint ventures with a foreign business entity in light industry of Ukraine has not yielded positive results - most of them still remain unprofitable, leading to massive bankruptcies and liquidation of enterprises in this sector. In general, between 2010 and 2017, the number of business entities engaged in textile manufacturing, clothing, leather, leather goods and other materials decreased by 4602 units or to $22 \%$ [13].

The sectoral level of the problem solution of import dependence and general stagnation of industries is seen in the creation of the so-called «international trading center» - the common platform for enterprises of trade and international development, based on the cooperation of enterprises in Ukraine, Europe, America and the Middle East. The creation of such a center involves: simplifying the dialogue between representatives of Ukrainian business entities and foreign partners; supply of raw materials; promotion of Ukrainian brands on world markets; organization of business meetings abroad; marketing analysis of world markets for clothing and footwear.

Another problem that needs to be addressed is the dependence of industries upon imports of intermediate consumption, in particular light industry. It is the question of the lack of raw materials of national origin for loading capacities of textile and garment enterprises. As a result, the majority of them redirected their activities from the production of finished goods into free circulation to the provision of services for the processing of tolling raw materials of foreign orders. The solution to the problem of the lack of raw materials is possible either by establishing long-term relationships with foreign manufacturing companies under the conditions of joint activity and distribution of products, or by introducing attractive conditions for the production of raw materials for fabrics of natural and synthetic origin in Ukraine in order to attract capital from a foreign entity.

Similar situation has also happened in the field of mechanical engineering - almost $90 \%$ of the industry's output is exported from the country under the category of «finished goods made from tolling raw materials». However, this initially concerns production of computers, electronic and optical products, electrical equipment, that is the production of components that are to be consumed for the manufacture of finished products in the country of origin of the tolling raw materials or even in the third country. This model of relationship is based on the inclusion of Ukrainian enterprises into global value chains in low-tech and low-income segments. 
In order to increase the level of technological development of the national business it is necessary to expand co-operation in the scientific and production sphere with the world leaders in mechanical engineering, to reorient domestic manufacturers to implement environmental European standards and the mobility of production in relation to the needs of consumers, to involve international automobile companies to build capacities in their own territory, and to revitalize the economy, which is to provide access to cheap credit resources for the producers and increase purchasing capacity of consumers.

The example of international co-operation in the field of mechanical engineering is series of agreements between Ukraine and the CIS countries, among them are the following: the Agreement on circulation of goods and industrial cooperation in the field of mechanical engineering on inter connected basis of December 9, 1994, No. 997 747 [14], the Agreement on cooperation in the field of mechanical engineering of September 24, 1993, No. 997 011 [15], the Agreement on general conditions and mechanisms for supporting the development of industrial cooperation between enterprises and industries of the member-states of the Commonwealth of Independent States of December 23, 1993, No. 997 014 [16].

In the Agreement on cooperation in the field of mechanical engineering dated September 24, 1993, No.997_011, the CIS member states declare the following: «... in order to preserve the created production potential of the machine-building enterprises of the Parties and its national use, as well as continuous improvement of the manufactured products, the Parties are to conclude bilateral and multilateral long-term agreements on the preservation and development of specialization and co-operation of machinebuilding enterprises, which provide mutual supply of finished products, raw materials, materials, semi-finished products, component parts, spare parts, etc. necessary for the manufacturing of mentioned products, using where it is appropriate, the clearing basis of settlements, as well as agreements on economic, scientific, technical and other types of cooperation in the field of mechanical engineering ...» [17]. The main advantages for the enterprises of the machine-building industry coming out of this Agreement are the following: provision of payments crediting for inter-supply of industrial products to machine-building enterprises; clearing enterprises of mechanical engineering from collection of customs duties at mutual deliveries of products.

Obviously, the existing for decades cooperative ties between Ukrainian enterprises and CIS partners have been substantially shortened and in the case of enterprises with the Russian Federation they have been cut off. At the same time, the way of diversification towards new non-resident counterparties is promising.

We see the potential for significant changes through the mechanism of international co-operation for the pharmaceutical industry in Ukraine, which also reached critical import dependency limits. Over the past 10 years, the trend has been stipulated reduction of the domestic medicinal products 
share on pharmaceutical market from $39 \%$ in monetary terms in 2015 to $25 \%$ in 2017. This situation is explained by several circumstances. The growing market of domestic pharmaceutical companies in 2015 accounted 160 entities, among which 47 enterprises producing substances, including oxygen and alcohol (29,3\%), 43 entities (26,9\%) manufacturing complex dosage forms in wide assortment; $7(4,4 \%)$ specializing only on manufacture of infusion solutions; other subjects of pharmaceutical production were represented by low-power enterprises producing up to 5 types of medicines.

Consequently, the Concept for development of the pharmaceutical segment within the healthcare sector of Ukraine for 2011-2020 dated 13.09.2010 № 769 identified the main direction of the formation of wide range of medicines for domestic production, taking into account economic expediency and the possibility of manufacturing import-replacing medicines.

The selective implementation of European norms for the functioning of domestic pharmaceutical companies leads to their reduction in its quantity. Such a situation could have been avoided under the condition of comprehensive implementation of European norms, in particular, the widespread implementation of contractual forms of working (contract manufacturing), the practical implementation of clear and transparent criteria for good manufacturing practices, etc. [17].

Contract production is the production by order at capacity of an independent manufacturer, which ensures the complete preservation of the technological cycle and quality control of finished products in accordance with the requirements of the customer. The main factor in the development of contract manufacturing as a special sector of the pharmaceutical industry is the scientific research increase in cost. Depriving the expenses for production, pharmaceutical companies could send more funds to create new drugs [18].

In recent years, the practice of transferring individual stages and operations in the production, packaging and quality control of drugs from the main contractor to contractor has been increasingly spread.

Ukraine became the first CIS country to establish itself as a member of the Pharmaceutical Inspection Cooperation System (PICS), which should facilitate the registration of foreign drugs in Ukraine as well as stipulate the entering of Ukrainian pharmaceutical products into the markets of countries participating in the agreement. But the greatest benefit from membership in the merger will receive companies that are planning to start contract manufacturing in Ukraine. Nowadays, there are 10-20 main manufacturers of pharmaceutical products under this contract in the world. The annual average volume of leading companies is $\$ 200$ million and they represent a significant part of the world market. Along with the leading companies there are medium and small contract firms, the exact number of them is unknown (approximately 900) [19].

The situation in the drug contract manufacturing field began to change for better for the Ukrainian business (there were GMP-certified plants with modern equipment, appropriate degrees of cleanliness of industrial premises, 
etc.) Companies that are not able to provide the proper quality or the volumes of drugs production at their own expense, forced to choose production partners for themselves [20].

Conclusion. Investigation of the cooperative component of Ukraine's import substitution strategy makes it possible to attain the following conclusions and generalizations:

$>$ construction of long-term cooperative relations with foreign counterparts as a strategy for improving the quality and structure of the level of import dependence of the national economy in the conditions of modern Ukraine is not implemented properly; having a significant number of international agreements on cooperation Ukraine, in practice, does not use their full potential: some of them ceased to operate (in the case of enterprises with the Russian Federation), others are mostly of declarative nature;

$>$ successful foreign experience points out the possibility of using different forms of cooperation to include creation of the cross border of the added value chains, in particular, by shifting the emphasis from investment to non-investment forms of cooperative relations. It creates opportunities for the inclusion of national business into global processes of added value creation, absorption of technologies and further development of their own products that would compete with imports;

$>$ governmental support of import substitution requires a balanced and coordinated approach; it may be implemented through the support of national enterprises within those branches of industry that are already able to compete with foreign suppliers of business services, as well as through the influence on external suppliers in order to encourage them to create assembly manufacturing in Ukraine with their further localization, especially high-tech processes and operations.

Despite the fact that modern Ukraine faced many complicated challenges: economic, political, social, security; as well as the undeniable fact that it isn't able to deal with them alone, to this day it doesn't affect the level of the cooperative component significance of the overall development strategy state, and not only in the part of balanced import substitution.

\section{REFERENCES}

1. Kramar, O. (2016). Ne mozhemo chy ne khochemo. Chy mozhlyve v Ukraini importozamishchennia [We cannot or we do not want. Is import substitution possible in Ukraine]. Ukrainskyi tyzhden - Ukrainian Week. Retrieved from https://www.chasipodii.net/article/17136 [in Ukrainian].

2. Rudnichenko, Ye. M., Havlovska, N. I., \& Havlovska, V. I. 2018.Hlobalizatsiia, importozamishchennia ta ekonomichna bezpeka derzhavy: vzaiemovplyv ta vzaiemozalezhnist [Globalization, import substitution and economic security of the state: mutual influence and interdependence]. Biznes Inform - Business Inform, 4. 26-32 [in Ukrainian].

3. Mazaraki, A., Melnichenko, S., Duginets, G. et al. (2018). Ukrainian economy growth imperatives. Prague: Coretex CZ SE [in Ukrainian]. 
4. Melnyk, T. M., \& Puhachevska, K. S. (2015). Perspektyvy importozamishchennia v Ukraini. Visnyk Kyi'v. nac. torg.-ekon. un-tu - Herald of Kyiv National University of Trade and Economics, 2, 16-33 [in Ukrainian].

5. Revak, I. O. (2018). Realizatsiia modeli innovatsiinoho rozvytku ta stymuliuvannia importozamishchennia - imperatyvy ekonomichnoi bezpeky Ukrainy. Naukovyi visnyk Lvivskoho derzhavnoho universytetu vnutrishnikh sprav - Scientific herald of Lviv State University of Internal Affairs. Seriia ekonomichna. Is. 1. (pp. 104-115) [in Ukrainian].

6. Lupak, R. L., \& Lykholat, S. M. (2017). Identyfikatsiia kontseptualnykh kharakterystyk i vzaiemozviazkiv protsesiv importozamishchennia ta zabezpechennia ekonomichnoi bezpeky derzhavy. Scientific Bulletin of the Lviv State University of Internal Affairs. Seriia ekonomichna. Is. 2, 66-74 [in Ukrainian].

7. Brytskyi, R. M. (2016). Neobkhidnist udoskonalennia derzhavnoi polityky importozamishchennia i problemy mizhnarodnoi ekonomiky pislia vstupu Ukrainy do zony vilnoi torhivli z krainamy YeS. Naukovyi visnyk Uzhhorodskoho natsionalnoho universytetu - Scientific Bulletin of Uzhgorod National University. Seriia: Mizhnarodni ekonomichni vidnosyny ta svitove hospodarstvo. Is. 7. Part 1, (pp. 48-53) [in Ukrainian].

8. Martins, A. C., \& Araujo, J. T. (2018). Import Substitution with Labor Misallocation. The World Bank. Retrieved from https://elibrary.worldbank.org/doi/abs/10.1596/ 1813-9450-8542 [in English].

9. Adewale, A. R. (2017). Import substitution industrialisation and economic growth Evidence from the group of BRICS countries. Future Business Journal, 2, 138-158 [in English].

10. Galiani, S., \& Somaini, P. (2018). Path-dependent import-substitution policies: the case of Argentina in the twentieth century. Latin American Economic Review. Retrieved from https://latinaer.springeropen.com/articles/10.1007/s40503-017-0047-4 [in English].

11. Statystychni dani «Tablytsia «vytraty-vypusk» (v tsinakh spozhyvachiv) za 20152017 roky» [Statistical data «Table of expense-emission» (consumer price) for 20152017»]. Retrieved from http://www.ukrstat.gov.ua [in Ukrainian].

12. Statystychnyi zbirnyk «Zovnishnia torhivlia Ukrainy tovaramy ta posluhamy»Statistical Herald «Foreign Trade of Ukraine with Goods and Services». (2012-2017). Derzhavna sluzhba statystyky Ukrainy. Retrieved from https://ukrstat.org[in Ukrainian].

13. Statystychni dani shchodo kilkosti subiektiv hospodariuvannia za vydamy ekonomichnoi diialnosti za 2001-2017 rr. [Statistical data on the number of economic entities by types of economic activity for 2001-2017]. Derzhavna Sluzhba Statystyky Ukrainy. Retrieved from https://ukrstat.org [in Ukrainian].

14. Uhoda pro tovaroobih ta vyrobnychu kooperatsiiu $\mathrm{v}$ haluzi mashynobuduvannia na vzaiemopohodzhenii osnovi № 997 392 vid 09.12.1994 [Contract on goods circulation and industrial cooperation in the field of mechanical engineering on mutually agreed basis from 09.12.1994 № 997_392]. Retrieved from https://zakon.rada.gov.ua/ laws/show/997_392 [in Ukrainian].

15. Uhoda pro spivrobitnytstvo v haluzi mashynobuduvannia № 997_011 vid 24.09.1993 [Agreement on cooperation in the field of mechanical engineering № 997_011dated September 24, 1993]. Retrieved from https://zakon.rada.gov.ua/laws/show/997_011 [in Ukrainian].

16. Uhoda pro zahalni umovy i mekhanizm pidtrymky rozvytku vyrobnychoi kooperatsii pidpryiemstv i haluzei derzhav-uchasnyts Spivdruzhnosti Nezalezhnykh Derzhav № 997014 vid 14.03.1995 [Agreement on general conditions and mechanism for supporting the development of industrial cooperation between enterprises and industrialbranches of the member-states of the Commonwealth of Independent States №997_014 dated March 14, 1995]. Retrieved from https://zakon.rada.gov.ua/ laws/show/997_014 [in Ukrainian]. 
17. Nakaz Ministerstva okhorony zdorovia Ukrainy «Pro zatverdzhennia Kontseptsii rozvytku farmatsevtychnoho sektoru haluzi okhorony zdorovia Ukrainy na 2011-2020 roky» № 769 vid 30.09.2013 [Order of the Ministry of Healthcare of Ukraine «On Approval of the Concept for the Development of the Pharmaceutical Sector in the Healthcare Industry of Ukraine for 2011-2020» № 769dated September 30.09.2013.]. Retrieved from https://zakon.rada.gov.ua/rada/show/v0769282-10 [in Ukrainian].

18. Fleming, E., \& Ma, P. (2002). Drug life-cycle technolo-gies. Nat. Rev. Drug. Discov. Vol. 1, 10, 751-752 [in English].

19. Ponomarenko, M. S., Tkachuk I. O., \& Zahorii H. V. (2012). Rol ta mistse kontraktnykh vidnosyn $\mathrm{v}$ umovakh farmatsevtychnoho rynku [The Role and Place of Contract Relations in the Conditions of the Pharmaceutical Market]. Upravlinnia, ekonomika ta zabezpechennia yakosti v farmatsii - Management, Economics and Quality Assurance in Pharmacy, 26, 78-84 [in Ukrainian].

20. Mohyliuk, V. (2011). Farmatsevtycheskaia otrasl [Pharmaceutical industry], 6(29), 84-86 [in Russian].

Articles submitted to editor office of 22.05.2019.

\section{Кудирко Л., Самсонова Л. Коопераційна складова стратегї̈ імпорто- заміщення Украӥни.}

Постановка проблеми. Річні витрати українців на імпортні товари наближаються до 1 трлн грн. За даними Державної служби статистики Украӥни, за останні 14 років частка вироблених у крайні споживчих товарів у торговельній мережі підприємств має тенденцію до збільшення. В Україні спостерігається неадекватна тенденція: частка так званого критичного імпорту, машин та обладнання, потрібних для модернізачії економіки щороку зменшується, натомість вироблені за кордоном споживчі товари посилюють позиції на внутрішньому ринку.

Аналіз останніх досліджень і публікацій. Загальнотеоретичні та практичні аспекти застосування політики імпортозаміщення знайшли відображення у наукових праиях вітчизняних та зарубіжних учених: І. Дунаєва, Я. Жаліло, А. Мазаракі, С. Пазізіної, В. Точиліна, Л. Шинкарука та ін. Питання розробки стратегї̈ імпортозаміщення практично не розглядається з урахуванням складової міжнародної кооперації як інструменту подолання жорсткої імпортозалежності галузей економіки.

Метою дослідження є вивчення можливостей міжнародної кооперачійної взаємодії у подоланні критичного рівня імпортозалежності країни.

Матеріали та методи. Інформаџійна база: наукові публікаџії вітчизняних вчених, статистичні дані ДССУ, НПА України. Під час написання статті використано такі методи наукового дослідження: аналізу та синтезу, статистичні.

Результати дослідження. Проаналізовано показники імпортозалежності видів економічної діяльності України. Досліджено особливості переробки давальницької сировини в Україні за окремими товарними групами. Надано характеристику стану окремих галузей (легка промисловість, машинобудування, фармакологія) та розкрито перспективи вирішення проблеми імпортозалежності через розвиток міжнародної внутрішньо- та міжгалузевої кооперації.

Висновки. Дослідження коопераційної складової стратегї імпортозаміщення Украйни продемонструвало, щчо такий інструмент. як побудова міцних коопераиійних відносин з іноземним сектором з метою розвитку наиіонального виробництва майже не застосовується.

Ключові слова: стратегія імпортозаміщення, імпортозалежність, міжнародна кооперація, контрактне виробництво, переробка давальницької сировини. 